\title{
INTERNET NETWORK CLASSIFICATION IN MALIKUSSALEH UNIVERSITY USING NAÏVE BAYES METHOD
}

\author{
Eva Darnila ${ }^{\bowtie}$, Zara Yunizar, Dhyra Gibran Alinda \\ Departement of Informatics, Universitas Malikussaleh, Aceh Utara, Indonesia \\ Email: eva.darnila@unimal.ac.id
}

DOI: $\underline{\text { https://doi.org/10.46880/jmika.Vol5No1.pp48-53 }}$

\begin{abstract}
The utilize of web systems at this time is exceptionally critical, particularly for the world of instruction. In expansion to the significance of the web arrange, issues frequently emerge on the web arrange due to an expansive number of clients, the issues can be gotten at the UNIMAL campus incorporate moderate, harmed, and indeed not sent information to its goal since the organize activity isn't ideal. To be able to optimize the web organize by prioritizing organize activity. In this consider, the Credulous Bayes calculation is utilized for the classification handle of organize activity capture information. The application utilized to capture organize activity is the Wireshark application. Utilizing the Credulous Bayes calculation to watch the comes about of organize test information through a calculation prepare that has tall precision. To be specific at the Workforce of Designing 95.73\% with a likelihood of testing comes about is 0.00015946 web browsing, 0.00000007 downloads, 0.00008691 gushing, 0.00008497 social media, 0.00000014 floodings.
\end{abstract}

Keyword: Wireshark, Classification, Nä̈ve Bayes Methods.

\section{INTRODUCTION}

In today's advanced life, the improvement of data innovation is so quick that it is taken after by the improvement of communication, particularly the improvement of the web. This data innovation has made the communication preparation less demanding, specifically by dispensing with remove and time which were considered as limitations, in this way requiring a incredible require for Indonesia to utilize the Web. The utilize of the web is a critical prerequisite to bolster campus execution and exercises. The foremost imperative portion of the Web framework given by the campus is the accessibility of adequate transmission capacity to guarantee smooth information activity on the Web. More often than not, the sum of accessible transfer speed is inadequately, particularly amid top hours and dynamic college periods (Prathivi, 2015).

With the tall request and utilization of arrange innovation, clients anticipate the arrange to attain greatest levels of efficiency and security. For illustration, there's a problem at the UNIMAL campus, since arrange activity isn't ideal, the information sent is exceptionally moderate, harmed, and indeed cannot reach its goal. Subsequently, analyzing arrange activity is one way to get it the utilize of organize communication conventions, so that it can be utilized as a premise for deciding arrange activity need (Dibawan, Widyantara, \& Linawati, 2016). The rectify classification of Web organize activity is exceptionally vital, particularly in arrange design plan, organize administration, and arrange security. The classification is based on the number of sorts of communication exercises controlled by organize conventions. Analyzing organize activity is one way to get it to utilize arrange communication conventions so that it can be utilized as a premise for deciding arrange activity need (Subrata, Widyantara, \& Linawati, 2016).

With respect to the classification of web activity, a few ponders have been carried out utilizing the Gullible Bayes calculation. As can be seen from the clarification over, the application of the Gullible Bayes calculation may be a solution that can be connected to the web activity classification instrument. In expansion, analysts will take Malikussaleh College Web activity as a case to assist assess the application performance of the Credulous Bayes calculation within the campus Web activity classification. The objective is to progress execution on the UNIMAL arrange and as a reference for directors in organize administration. The classification instrument utilized is to decide the likelihood of UNIMAL web activity being captured on a UNIMAL organize switch by utilizing the Wireshark application.

\section{RESEARCH METHODS}

Classification is the method of finding a demonstrate or work that portrays or classifies information into classes. Classification includes the 
method of analyzing the characteristics of a question and inserting that object into a class. In common, classification may be a demonstrate made to portray a foreordained set of information classes or concepts. Construct models by analyzing speculative records into foreordained classes (called course attributes) (Dibawan et al., 2016).

The Naive Bayes algorithm is a calculation that's included within the classification procedure. Naïve Bayes could be a classification proposed by the British researcher Thomas Bayes utilizing likelihood and measurable strategies that foresee future openings based on past encounters, so it is called the Bayes hypothesis. The Bayes hypothesis condition is as takes after (Dibawan et al., 2016):

$P(H \mid X)=\frac{P(X \mid H) * P(H)}{P(X)}$

Where:

X : Data with an unknown class.

$\mathrm{H} \quad$ : Data hypothesis $\mathrm{X}$ a class.

$\mathrm{P}(\mathrm{H} \mid \mathrm{X}) \quad$ : The probability of hypothesis $\mathrm{H}$

based on condition $\mathrm{X}$ (Posterior).

$\mathrm{P}(\mathrm{H}) \quad$ : Hypothesis probability $\mathrm{H}$ (Prior).

$\mathrm{P}(\mathrm{X} \mid \mathrm{H}) \quad$ : Probability $\mathrm{X}$ based on the

conditions in the hypothesis

$\mathrm{P}(\mathrm{X}) \quad$ : Probability X.

To clarify the Credulous Bayes hypothesis, it ought to be famous that the classification preparation requires a part of clues to decide which category is appropriate for the test being analyzed. In this manner, the Bayes hypothesis specified over is balanced as takes after:

$P(H \mid X)=\frac{P(C) P\left(F_{1} \ldots F_{n} \mid C\right)}{P\left(F_{1} \ldots F_{n}\right)}$

Where the variable $\mathrm{C}$ speaks to the course, whereas the variable F1 ... Fn speaks to the characteristics of the enlightening required to perform the classification. At that point, the equation depicts the likelihood of a particular characteristic test entering course $\mathrm{C}$ (back), to be specific the chance of course $\mathrm{C}$ (sometime recently the passage of the test, it is frequently called a earlier), increase by the likelihood of event of the characteristic test $\mathrm{C}$ (probability), separated by the likelihood of event of the characteristics of the test at the same time. worldwide (prove), hence, the over equation can too be composed essentially as takes after
Posterior $=\frac{\text { likelihood } x \text { prior }}{\text { evidence }}$

Evidence value is always assigned to each category in the sample, and the posterior value is then compared with the posterior value of other categories to determine the sample category, further elaboration of the Bayes formula is done by elaboration $(\mathrm{C} \mid \mathrm{F} 1$, .., Fn) Use the following multiplication rule:

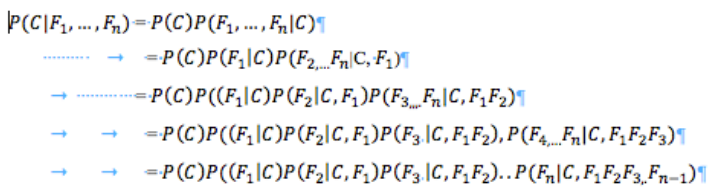

It appears that the results of these descriptions lead to increasingly complex determinants affecting the probability value, which are almost impossible to analyze individually, and as a result of which these calculations become difficult to carry out, it is here that the assumption of very high independence (naivety) is used. ). Whereas each clue $\left(F_{-} 1 \llbracket, F \rrbracket \_2 \llbracket, \ldots F \rrbracket\right.$ n) is independent (independent) of each other, with this assumption, the following similarities apply as follows:

$$
\begin{gathered}
P\left(P_{i} \mid P_{j}\right)=\frac{P\left(P_{i} \cap F_{j}\right)}{P\left(F_{j}\right)}=\frac{P\left(F_{i}\right) P\left(F_{j}\right)}{P\left(F_{j}\right)}=P\left(F_{i}\right) \\
\text { Untuk } i \neq j, \text { sehingga } \\
P\left(F_{i} \mid C, F_{i}\right)=P\left(F_{i} \mid C\right) \ldots \ldots \ldots(4)
\end{gathered}
$$

From the above equation, it can be concluded that the naive assumption of independence makes the conditions of probability simple, allowing the calculation to be carried out, and then, the translation of $\mathrm{P}\left(\mathrm{C} \mid \mathrm{F} \_1, \ldots, \mathrm{F}_{-} \mathrm{n}\right)$ can be simplified to:

$$
\begin{aligned}
& P\left(C \mid F_{1}, \ldots, F_{n}\right)= \\
& P(C) P\left(F_{1} \mid C\right) P\left(F_{2} \mid C\right) P\left(F_{3} \mid C\right) \ldots=(C) \prod_{i}^{n}= \\
& 1 P\left(F_{i} \mid C\right) \ldots \ldots \ldots \ldots \ldots \ldots \ldots \ldots \ldots \ldots \ldots \ldots \ldots \ldots \ldots \ldots \ldots \ldots \ldots \ldots \ldots \ldots
\end{aligned}
$$

The last stage is to test the accuracy of data mining using the Naive Bayes algorithm. The method of calculating the accuracy is as follows.

The formula for calculating insurance is written as below:

a. Acuracy useful for measuring the performance of a method.

Acuracy $=$

$\frac{\text { the amount of data predicted is correct }}{\text { the total number of predictions }} \times 100 \%$ 
b. Error is useful for measuring the degree of mismatch.

Error $=$

$\frac{\text { the amount of data predicted is wrong }}{\text { the total number of predictions }} \times 100 \% \ldots(7)$

Retrieving Network Traffic using the Wireshark application is done by capturing traffic on the network. In recorded network traffic, about hundreds of thousands of traffic are generated every five minutes. However, the number of records generated is not the same. The unequal number of traffic records is caused by the inequality of the communication model in the computer network carried out by the user. Network traffic capture model from wireshark is as shown below:



Figure 1. Capturing Network traffic

Wireshark is one of the numerous Arrange Analyzer disobedient that are broadly utilized by Arrange Chairmen to analyze arrange execution. Wireshark is broadly enjoyed since of its interface that employments a Graphical Client Interface (GUI) or a graphical show. Wireshark is utilized for arranging investigating, examination, program and communication convention improvement, and instruction. Wireshark is broadly utilized by Arrange Directors to analyze arrange execution. Wireshark is able to capture information/data passing through an organization that we watch within the frame of organized activity. The benefits of utilizing the Wireshark application areas takes after (Sudarma \& Hostiadi, 2013), Capturing data or bundle information sent and gotten on computer systems, understanding exercises that happen on computer systems, understanding and analyzing the execution of our computer systems, such as information get to / sharing speed and a arrange association to the web, watching the security of the computer network.

The plot of the UNIMAL web organize classification framework utilizing the Naïve Bayes calculation is as takes after:

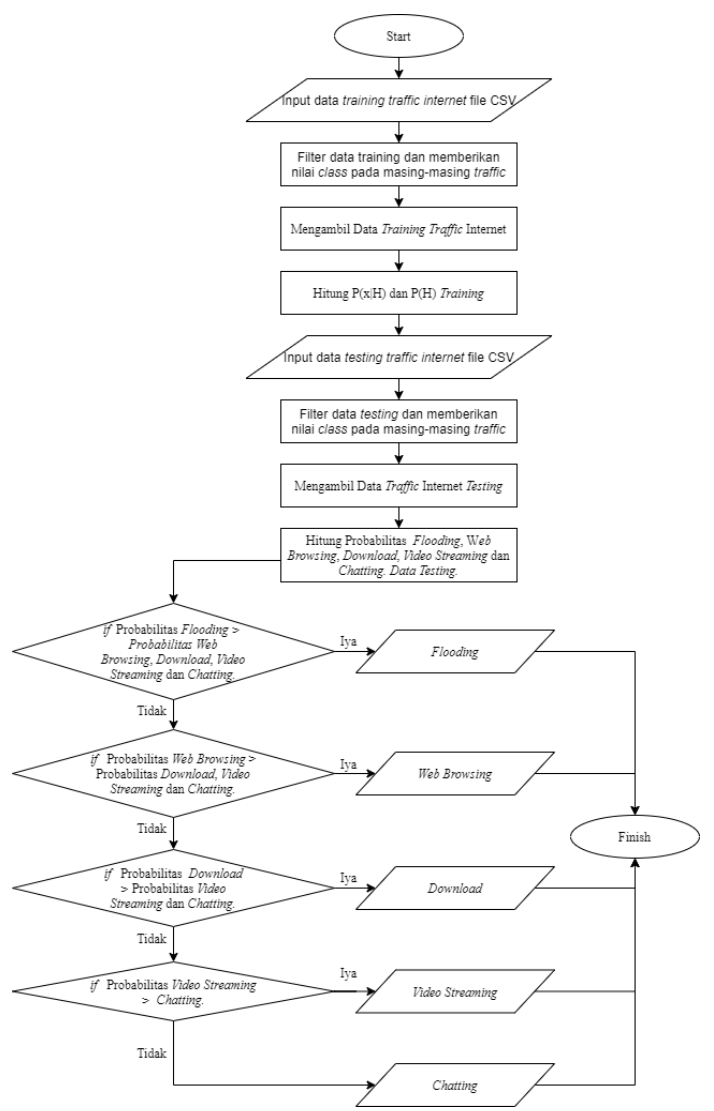

Figure 2. System Scheme

\section{RESULT AND DISCUSSION}

Building workforce preparing information were collected from 1/8/2020 - 12/9/2020, with a add up to web activity information of 10,945 , comprising of 9,623 web browsing activity information, 378 spilling activity information, 387 social media information, 66 download information, and 491 identified information as flooding. Testing information or test information could be a raw fabric that's intentionally made to assist the investigation process in a information mining framework, in more detail, testing information can be seen within the taking after table:

Table 1. Internet traffic data table

\begin{tabular}{|c|c|c|c|c|}
\hline $\begin{array}{l}\mathbf{N} \\
\mathbf{O}\end{array}$ & DOMAIN & $\begin{array}{l}\text { PROT } \\
\text { OCOL }\end{array}$ & $\begin{array}{l}\text { PO } \\
\text { RT }\end{array}$ & $\begin{array}{c}\text { CLASSI } \\
\text { FICATI } \\
\text { ON }\end{array}$ \\
\hline 1 & $\begin{array}{l}\text { external.fplm4- } \\
\text { 1.fna.fbcdn.net }\end{array}$ & $\begin{array}{c}\text { HTTP } \\
\text { S }\end{array}$ & $\begin{array}{c}44 \\
3\end{array}$ & ? \\
\hline
\end{tabular}

For data testing at the Engineering faculty, it can be calculated P (Ci) or the number of classes / labels. The number of classes / labels is 5 , namely web browsing, downloading, streaming, flooding and social media. 
$\mathrm{P}(\mathrm{Y}=$ label / class $)=$ web browsing, number of labels, class / total amount of data

$\mathrm{P}(\mathrm{Y}=$ web browsing $)=9623 / 10945=0.87921425$

$\mathrm{P}(\mathrm{Y}=$ download $)=66 / 10945=0.00603015$

$(\mathrm{Y}=$ streaming $)=378 / 10945=0.03453632$

$\mathrm{P}(\mathrm{Y}=$ social media $)=387 / 10945=0.03535861$

$\mathrm{P}(\mathrm{Y}=$ flooding $)=491 / 10945=0.04486067$

In calculating $\mathrm{P}(\mathrm{X} \mid \mathrm{Ci})$ or the number of the same cases with the same class. To avoid results with the number 0 (zero), laplace correction is used for each calculated data.

In label class $\mathrm{Y}=$ web browsing, the amount of data labeled class $\mathrm{Y}=$ web browsing is 9623

$\mathrm{P}($ domain $=$ external. fplm $4-1$. fna. fbcdn. net $\mid \mathrm{Y}$

$$
\begin{aligned}
& =\text { web browsing })=\frac{(1+1)}{(9623+5)} \\
& =0.00020773
\end{aligned}
$$

$\mathrm{P}($ protocol $=$ HTTPS $\mid \mathrm{Y}=$ web browsing $)$

$$
\begin{aligned}
= & \frac{(9036+1)}{(9623+5)}=0.93861654 \\
\mathrm{P}(\text { port }=443 \mid \mathrm{Y} & =\text { web browsing })=\frac{(8955+1)}{(9623+5)} \\
& =0.93020357
\end{aligned}
$$

At Label class $\mathrm{Y}=$ download, the amount of data labeled class $\mathrm{Y}=$ download is 66 $\mathrm{P}($ domain $=$ external. fplm $4-1$. fna. fbcdn. net $\mid \mathrm{Y}$

$$
\begin{aligned}
&=\text { download })=\frac{(0+1)}{(66+5)} \\
&= 0.01408451 \\
& \mathrm{P}(\text { protocol }=\text { HTTPS } \mid \mathrm{Y}=\text { download })=\frac{(1+1)}{(66+5)} \\
&=0.02816901 \\
& \mathrm{P}(\text { port }=443 \mid \mathrm{Y}=\text { download })=\frac{(1+1)}{(66+5)} \\
&=0.02816901
\end{aligned}
$$

On Label class $\mathrm{Y}=$ streaming, the amount of data labeled class $\mathrm{Y}=$ streaming is 378 $\mathrm{P}($ domain $=$ external. fplm $4-1$. fna. fbcdn. net $\mid \mathrm{Y}$

$$
\begin{aligned}
& =\text { streaming })=\frac{(0+1)}{(378+5)} \\
& =0.00261097
\end{aligned}
$$

$\mathrm{P}($ protocol $=$ HTTPS $\mid \mathrm{Y}=$ streaming $)$

$$
=\frac{(375+1)}{(378+5)}=0.98172324
$$

$\mathrm{P}($ port $=443 \mid \mathrm{Y}=$ streaming $)=\frac{(375+1)}{(378+5)}$

$$
=0.98172324
$$

In label class $\mathrm{Y}=$ social media, the amount of data labeled class $\mathrm{Y}=$ social media is 387 $\mathrm{P}($ domain $=$ external. fplm $4-1$. fna. fbcdn. net $\mathrm{Y}$

$$
\begin{aligned}
& =\text { sosial media })=\frac{(0+1)}{(387+5)} \\
& =0.00255102
\end{aligned}
$$

$\mathrm{P}($ protocol $=$ HTTPS $\mid \mathrm{Y}=$ sosial media $)$

$$
=\frac{(385+1)}{(387+5)}=0.98469388
$$

$\mathrm{P}($ port $=443 \mid \mathrm{Y}=$ sosial media $)=\frac{(374+1)}{(387+5)}$

$$
=0.95663265
$$

In label class $\mathrm{Y}=$ flooding, the amount of data labeled class $\mathrm{Y}$ flooding is 491

$\mathrm{P}($ domain $=$ external. fplm $4-1$. fna. fbcdn. net $\mid \mathrm{Y}$

$$
\begin{aligned}
& =\text { flooding })=\frac{(0+1)}{(491+5)} \\
& =0.00201613
\end{aligned}
$$

$\mathrm{P}($ protocol $=$ HTTPS $\mid \mathrm{Y}=$ flooding $)$

$$
\begin{gathered}
=\frac{(0+1)}{(491+5)}=0.00201613 \\
\mathrm{P}(\text { port }=443 \mid \mathrm{Y}=\text { flooding })=\frac{(386+1)}{(491+5)} \\
=0.78024194
\end{gathered}
$$

To calculate the value of $\mathrm{P}(\mathrm{Ci}) * \mathrm{P}(\mathrm{X} \mid \mathrm{Ci})$ or multiply all the variables / classes of web browsing, downloading, streaming, flooding and social media. $\mathrm{P}(\mathrm{Y}=$ web browsing $)=\mathrm{P}($ domain $\mid$ web browsing $)$ * $\mathrm{P}($ protocol $\mid$ web browsing $) * \mathrm{P}($ port $\mid$ web browsing $)$ * $\mathrm{P}(\mathrm{Y} \mid$ web browsing $)$

$$
\begin{aligned}
& =0.00020773 * 0.93861654 * \\
& 0.93020357 * 0.87921425 \\
& =0.00015946
\end{aligned}
$$

$\mathrm{P}(\mathrm{Y}=$ download $)=\mathrm{P}($ domain $\mid$ download $) * \mathrm{P}($ protocol | download $) * \mathrm{P}($ port $\mid$ download $) * \mathrm{P}(\mathrm{Y} \mid$ download $)$

$$
=0.01408451 * 0.02816901 *
$$

$0.02816901 * 0.00603015$

$=0.00000007$

$\mathrm{P}(\mathrm{Y}=$ streaming $)=\mathrm{P}($ domain $\mid$ streaming $) *$ $\mathrm{P}($ protocol $\mid$ streaming $) * \mathrm{P}($ port $\mid$ streaming $) * \mathrm{P}(\mathrm{Y}$ | streaming)

$$
\begin{gathered}
=0.00261097 * 0.98172324 * \\
0.98172324 * 0.03453632 \\
=0.00008691
\end{gathered}
$$

$\mathrm{P}(\mathrm{Y}=$ sosial media $)=\mathrm{P}($ domain $\mid$ sosial media $)$ * $\mathrm{P}($ protocol $\mid$ sosial media $) * \mathrm{P}($ port $\mid$ sosial media $)$ * $\mathrm{P}(\mathrm{Y} \mid$ sosial media $)$

$=0.00255102 * 0.98469388 *$

$0.95663265 * 0.03535861$

$=0.00008497$ 


$$
\begin{aligned}
& \mathrm{P}(\mathrm{Y}=\text { flooding })=\mathrm{P}(\text { domain } \mid \text { flooding }) * \mathrm{P}(\text { protocol } \\
& \begin{array}{r}
\mid \text { flooding }) * \mathrm{P}(\text { port } \mid \text { flooding }) * \mathrm{P}(\mathrm{Y} \mid \text { flooding }) \\
=0.00201613 * 0.00201613 * \\
0.78024194 * 0.04486067 \\
=0.00000014
\end{array}
\end{aligned}
$$

Compare the results of the largest probability value showing the status label class web browsing, downloading, streaming, flooding and social media, where the probability of web browsing class is higher with a probability of 0.00015946 so the data above is

\begin{tabular}{|c|c|c|c|c|c|}
\hline $\begin{array}{l}\mathbf{N} \\
\mathbf{0}\end{array}$ & Domain & $\begin{array}{l}\text { Prot } \\
\text { ocol }\end{array}$ & Port & $\begin{array}{c}\text { Classi } \\
\text { ficatio } \\
\mathbf{n}\end{array}$ & $\begin{array}{l}\text { Predi } \\
\text { ction }\end{array}$ \\
\hline 1 & $\begin{array}{l}\text { external.fplm4- } \\
\text { 1.fna.fbcdn.net }\end{array}$ & $\begin{array}{l}\text { HTT } \\
\text { PS }\end{array}$ & 443 & $\begin{array}{l}\text { browsi } \\
\text { ng }\end{array}$ & $\begin{array}{l}\text { brows } \\
\text { ing }\end{array}$ \\
\hline 2 & koinworks.com & $\begin{array}{l}\text { HTT } \\
\text { PS }\end{array}$ & 443 & $\begin{array}{l}\text { browsi } \\
\text { ng }\end{array}$ & $\begin{array}{l}\text { brows } \\
\text { ing }\end{array}$ \\
\hline 3 & $\begin{array}{l}\text { v10.events.data.mic } \\
\text { rosoft.com }\end{array}$ & $\begin{array}{l}\text { HTT } \\
\text { PS }\end{array}$ & 443 & $\begin{array}{l}\text { browsi } \\
\text { ng }\end{array}$ & $\begin{array}{l}\text { brows } \\
\text { ing }\end{array}$ \\
\hline 4 & $\begin{array}{l}\text { blogkoinworks.sgp1 } \\
\text { digitaloceanspaces. } \\
\text { com }\end{array}$ & $\begin{array}{l}\text { HTT } \\
\text { PS }\end{array}$ & 443 & $\begin{array}{l}\text { browsi } \\
\text { ng }\end{array}$ & $\begin{array}{l}\text { brows } \\
\text { ing }\end{array}$ \\
\hline 5 & $\begin{array}{l}\text { icono- } \\
49 \mathrm{~d} 6 . \mathrm{kxcdn} . \mathrm{com}\end{array}$ & $\begin{array}{l}\text { HTT } \\
\text { PS }\end{array}$ & 443 & $\begin{array}{l}\text { browsi } \\
\text { ng }\end{array}$ & $\begin{array}{l}\text { brows } \\
\text { ing }\end{array}$ \\
\hline 6 & dns.msftncsi.com & $\begin{array}{l}\text { HTT } \\
\text { PS }\end{array}$ & 443 & $\begin{array}{l}\text { browsi } \\
\text { ng }\end{array}$ & $\begin{array}{l}\text { brows } \\
\text { ing }\end{array}$ \\
\hline 7 & $\begin{array}{l}\text { youtube- } \\
\text { ui.l.google.com }\end{array}$ & $\begin{array}{l}\text { HTT } \\
\text { PS }\end{array}$ & 443 & $\begin{array}{l}\text { browsi } \\
\text { ng }\end{array}$ & $\begin{array}{l}\text { brows } \\
\text { ing }\end{array}$ \\
\hline 8 & s.ytimg.com & $\begin{array}{l}\text { HTT } \\
\text { PS }\end{array}$ & 443 & $\begin{array}{l}\text { browsi } \\
\text { ng }\end{array}$ & $\begin{array}{l}\text { brows } \\
\text { ing }\end{array}$ \\
\hline 9 & $\begin{array}{l}\text { d2r1yp } 2 \text { w } 7 \text { bby } 2 \text { u.cl } \\
\text { oudfront.net }\end{array}$ & $\begin{array}{l}\text { HTT } \\
\text { PS }\end{array}$ & 443 & $\begin{array}{l}\text { browsi } \\
\text { ng }\end{array}$ & $\begin{array}{l}\text { brows } \\
\text { ing }\end{array}$ \\
\hline 10 & $\begin{array}{l}\text { amplify.outbrain.co } \\
\mathrm{m}\end{array}$ & $\begin{array}{l}\text { HTT } \\
\text { PS }\end{array}$ & 443 & $\begin{array}{l}\text { browsi } \\
\text { ng }\end{array}$ & $\begin{array}{l}\text { brows } \\
\text { ing }\end{array}$ \\
\hline 11 & wzrkt.com & $\begin{array}{l}\text { HTT } \\
\text { PS }\end{array}$ & 443 & $\begin{array}{l}\text { browsi } \\
\text { ng }\end{array}$ & $\begin{array}{l}\text { brows } \\
\text { ing }\end{array}$ \\
\hline 12 & tr.outbrain.com & $\begin{array}{l}\text { HTT } \\
\text { PS }\end{array}$ & 443 & $\begin{array}{l}\text { browsi } \\
\text { ng }\end{array}$ & $\begin{array}{c}\text { brows } \\
\text { ing }\end{array}$ \\
\hline 13 & $\begin{array}{l}\text { api-glb- } \\
\text { apse1c.smoot.apple. } \\
\text { com }\end{array}$ & $\begin{array}{l}\text { HTT } \\
\text { PS }\end{array}$ & 443 & $\begin{array}{l}\text { browsi } \\
\text { ng }\end{array}$ & $\begin{array}{l}\text { brows } \\
\text { ing }\end{array}$ \\
\hline 14 & clients1.google.com & $\begin{array}{l}\text { HTT } \\
\text { PS }\end{array}$ & 443 & $\begin{array}{l}\text { browsi } \\
\text { ng }\end{array}$ & $\begin{array}{l}\text { brows } \\
\text { ing }\end{array}$ \\
\hline 15 & $\begin{array}{l}\text { a1838.dscb.akamai. } \\
\text { net }\end{array}$ & $\begin{array}{l}\text { HTT } \\
\text { PS }\end{array}$ & 443 & $\begin{array}{l}\text { browsi } \\
\text { ng }\end{array}$ & $\begin{array}{c}\text { brows } \\
\text { ing }\end{array}$ \\
\hline 16 & $\begin{array}{l}\text { is- } \\
\text { ssl.mzstatic.com.itu } \\
\text { nes- } \\
\text { apple.com.akadns.n } \\
\text { et }\end{array}$ & $\begin{array}{l}\text { HTT } \\
\text { PS }\end{array}$ & 443 & $\begin{array}{l}\text { browsi } \\
\text { ng }\end{array}$ & $\begin{array}{l}\text { brows } \\
\text { ing }\end{array}$ \\
\hline 17 & $\begin{array}{l}\text { gateway.fe.apple- } \\
\text { dns.net }\end{array}$ & $\begin{array}{l}\text { HTT } \\
\text { PS }\end{array}$ & 443 & $\begin{array}{l}\text { browsi } \\
\text { ng }\end{array}$ & $\begin{array}{c}\text { brows } \\
\text { ing }\end{array}$ \\
\hline 18 & $\begin{array}{l}\text { e6858.dsce9.akamai } \\
\text { edge.net }\end{array}$ & $\begin{array}{l}\text { HTT } \\
\text { PS }\end{array}$ & 443 & $\begin{array}{l}\text { browsi } \\
\text { ng }\end{array}$ & $\begin{array}{l}\text { brows } \\
\text { ing }\end{array}$ \\
\hline
\end{tabular}
included in the web browsing class.

The accuracy value in the Engineering Faculty data can be seen in Table 2 .

Table 2. Table of accuracy of Engineering faculty

\begin{tabular}{clcccc}
\hline $\begin{array}{c}\text { N } \\
\mathbf{0}\end{array}$ & Domain & $\begin{array}{c}\text { Prot } \\
\text { ocol }\end{array}$ & Port & $\begin{array}{c}\text { Classi } \\
\text { ficatio } \\
\text { n }\end{array}$ & $\begin{array}{c}\text { Predi } \\
\text { ction }\end{array}$ \\
\hline 19 & $\begin{array}{l}\text { www- } \\
\text { cdn.icloud.com.aka } \\
\text { dns.net }\end{array}$ & $\begin{array}{c}\text { HTT } \\
\text { PS }\end{array}$ & 443 & $\begin{array}{c}\text { browsi } \\
\text { ng }\end{array}$ & $\begin{array}{c}\text { brows } \\
\text { ing }\end{array}$ \\
20 & my.in-fbs.com & $\begin{array}{c}\text { HTT } \\
\text { PS }\end{array}$ & 443 & $\begin{array}{c}\text { browsi } \\
\text { ng }\end{array}$ & $\begin{array}{c}\text { brows } \\
\text { ing }\end{array}$ \\
\hline
\end{tabular}

$$
\begin{aligned}
& \text { Acuracy }=\frac{\text { the number of correct predictions }}{\text { the total number of predictions }} \\
& =\frac{(211+0+1+4+9)}{(220+0+1+4+9)} \\
& =\frac{224}{234} X 100 \%=95,73 \% \\
& \text { Error }=\frac{\text { number of wrong predictions }}{\text { the total number of predictions }} \\
& =\frac{(10+0+0+0+0)}{(221+0+1+4+9)} \\
& =\frac{10}{234} X 100 \%=4,27 \%
\end{aligned}
$$

Accuracy of $95.73 \%$ : Classification of internet traffic testing consisting of 220 web browsing, 0 downloads, 4 streams, 1 flooding and 9 social media, accurate 210 web browsing, 0 downloads, 3 streams, 1 flooding and 9 social media, with $95.73 \%$ percentage with 243 internet traffic data testing.

Error 4.27\%: Classification of internet traffic testing consisting of 220 web browsing, 0 downloads, 4 streaming, 1 flooding and 9 social media, the error is 10 web browsing, 0 downloads, 0 streaming, 0 flooding and 0 social media, with a percentage of $4.27 \%$ with 234 internet traffic data testing.

\section{CONCLUSION}

The results of the analysis and testing carried out on the previous system, the conclusions drawn, among others, that this application is able to classify internet traffic into flooding, web browsing, downloading, video streaming and social media. The size of the training data affects the length of the classification process, the greater the training data, the longer the classification process.

Training data is taken from internet traffic data from several faculties. At the Faculty of Engineering Data was taken for 30 days, starting from 1/8/2020 $12 / 9 / 2020$ a total of 10,945 data, where the results of the probability test data search obtained the following classification 0.00015946 web browsing, 0.00000007 downloads, 0.00008691 streaming, 0.00008497 social media, and 0.00000014 flooding.

At the Faculty of Economics, data is taken for 30 days, starting from 16/9/2020 - 30/10/2020 a total of 
3,902 data, where the results of the probability test data search get the following classifications of 0.00022630 web browsing, 0.00000177 downloads, 0.00023456 streaming, 0.00022124 social media, and 0.00000098 flooding.

At the Faculty of Social and Political Sciences, data was taken for 30 days, starting from 2/11/2020 $14 / 12 / 2020$ a total of 10,711 data, where the results of the probability test data search were obtained the following classifications were 0.00016715 web browsing, $\quad 0.00000078$ downloads, 0.00009011 streaming, 0.00008787 social media, and 0.00000016 flooding.

Testing internet traffic classification with the naïve Bayes algorithm uses 234 test data, on 10,945 Faculty of Engineering training data produces $95.73 \%$ accuracy and $4.27 \%$ error, for 3,902 Faculty of Economics training data produces $48.72 \%$ accuracy and $51.28 \%$ errors, and 10,711 Faculty of Social and Political Sciences training data resulted in an accuracy of $94.87 \%$ and an error of $5.18 \%$.

\section{REFERENCES}

Dibawan, I. M. B., Widyantara, I. M. O., \& Linawati. (2016). KLASIFIKASI TRAFIK INTERNET KAMPUS BERBASIS PROTOKOL JARINGAN MENGGUNAKAN ALGORITMA NAIVE BAYES. Jurnal SPEKTRUM, 3(2), 714.

Prathivi, R. (2015). Klasifikasi Data Trafik Internet Menggunakan Metode Bayes Network (Studi Kasus Jaringan Internet Universitas Semarang). Jurnal Transformatika, 12(2), 42. https://doi.org/10.26623/transformatika.v12i2.81

Subrata, K. K. A., Widyantara, I. M. O., \& Linawati, L. (2016). KLASIFIKASI PENGGUNAAN PROTOKOL KOMUNIKASI PADA TRAFIK JARINGAN MENGGUNAKAN ALGORITMA K-NEAREST NEIGHBOR. Majalah Ilmiah Teknologi Elektro, 16(1), 67. https://doi.org/10.24843/MITE.1601.10

Sudarma, M., \& Hostiadi, D. P. (2013). Klasifikasi Penggunaan Protokol Komunikasi Pada Nework Traffic Menggunakan Naive Bayes Sebagai Penentuan QoS. PROSIDING CSGTEIS 2013, 59-64. Universitas Udayana. 